International Journal of Forensic Science \& Pathology (IJFP)

ISSN 2332-287X

\title{
Sex Determination from Fourth Rib by Osteometric Analysis
}

Chand $\mathrm{M}^{1^{*}}$, Mittal S , Chouksey $\mathrm{V}^{3}$, Yashoda Rani ${ }^{4}$

${ }^{1}$ Senior Resident, Forensic Medicine and Toxicology, Lady Hardinge Medical College, New Delhi, India.

${ }^{2}$ Junior Resident (PG II ${ }^{\text {nd }}$ Year), Forensic Medicine and Toxicology, Lady Hardinge Medical College, New Delhi, India.

${ }^{3}$ Junior Resident (PG It ${ }^{\text {st }}$ Year), Forensic Medicine and Toxicology, Lady Hardinge Medical College, New Delhi, India.

${ }^{4}$ Professor and Head, Forensic Medicine and Toxicology, Lady Hardinge Medical College, New Delhi, India.

\begin{abstract}
There have been several studies showing that the sternal extremity of the fourth rib can be used in estimating age as well as in determining sex. An osteometric study of sexual dimorphism in the sternal ends of the fourth rib was collected from 266 (200 males and 66 females) individuals autopsied of known age, sex, and race was conducted in New Delhi, India. The height and width of the sternal end of the rib were measured with a calliper in each case. The sample was analyzed in three groups: young (phase 1-4), old (phase 4-7), and total sample (phase 1-7).

Results: The results indicated that the accuracy of sex determination was $84.7 \%$ in the young group (phase 1-4, age 15-32), $86.4 \%$ in the older group (phase 4-8, age 33-89).

Conclusion: It is important to note that sexual dimorphism can be assessable by using a single fourth rib in a Indian population from ages 14 to 85 . SIH of the rib is the most reliable parameter; APB follows it.
\end{abstract}

Keywords: Sex Determination; Sternal Rib; Discriminant Function; Human Identification.

\section{*Corresponding Author:}

Dr. Mahesh Chand Meena M.D,

Senior Resident, Forensic Medicine and Toxicology, Lady Hardinge Medical College, New Delhi-110001, India.

Tel: 9868807888

E-mail: drmahe2012@gmail.com

Received: May 02, 2015

Accepted: July 13, 2015

Published: July 15, 2015

Citation: Chand M, Mittal S, Chouksey V, Yashoda Rani (2015) Sex Determination from Fourth Rib by Osteometric Analysis. Int J Forensic Sci Pathol. 3(7), 148-151.

doi: http:/ /dx.doi.org/10.19070/2332-287X-1500036

Copyright: Mahesh Chand Meena ${ }^{\mathcal{O}} 2015$. This is an open-access article distributed under the terms of the Creative Commons Attribution License, which permits unrestricted use, distribution and reproduction in any medium, provided the original author and source are credited.

\section{Introduction}

Sex and age determinations are always crucial and usually problematic all the skeletonised cases, especially when an incomplete skeleton is received, and in many of the exhumed bodies. Forensic expert and anthropologists have turned their interest to obtain more information from fragmentary as well as smaller bones [1]. With this in mind, many apparently less sexually dimorphic fragmentary small bones have been analyzed to determine sex. These bones include the clavicle [2], sternum [3, 4], radius [5, 6], metacarpals and phalanges [7-10], metatarsals [11], vertebrae [12], and pelvis [13-18].
Based on hypothesis that populations differ from each other due to climate might be one of the factors determining bone formation besides genetic, nutritional and environmental factors [14, 15], the aging process and sexual dimorphism must be assessed separately. This is especially for those populations which are geographically distant from the population used to set the standard.

The Indian population is suitable for such an analysis because of its distance from North American whites. Indian researchers [16-18] initiated a similar to that of Iscan and associates' [19-21], where age related changes at the costochondral end of the fourth ribs collected at the autopsy were studied. Their research agreed with Iscan et al., [19-21] that ribs provide an accurate estimation of age in the adult.

Determination of sex from the rib has not been carried out extensively except for radiological studies [22-25]. To date there has been only one three published study known to us of sexual differentiation by direct examination and measurements of bony ribs [26]. There is no publication on determination of sex by rib measurements in Indian population in general, to our knowledge.

The aim of this study is to develop a set of formulas using discriminant function analysis, analogous to that of Iscan [26], with the expectation that they will be useful in determining the sex from the skeletal remains of unknown individuals.

\section{Materials and Methods}

The sternal end of the fourth rib was collected from 266 cases (200 males and 66 females) of known age and sex, referred to the Lady Hardinge Medical College mortuary for autopsy. Age 
was recorded from the police request forms to the nearest year. A short segment of the sternal end of the fourth rib was removed along with its costal cartilage. The specimens were left in a glass container filled with water for about three months. Bones were later boiled gently for about 30 minutes to remove the remaining soft tissue. The maximum superior-inferior height $(\mathrm{SIH})$ and the maximum Antero-posterior breadth (APB) of the sternal end of each specimen were measured by using a Vernier calliper to the nearest tenth of a millimetre. To control for the effect of age on sexual dimorphism, they was analysed in three age groups, that is, "young" (phases 1-4, mean ages 14-29), "old" (phases 4-7, mean ages. 30-85) and "total" (phases 1-7, mean ages 14 to
85). Ribs in phase 0 ( 2 males; 1 females) were excluded from the statistical analysis because they had not reached skeletal maturity. Specimens in phase 4 were considered transitional and were included in the analysis of both young and old groups in order to minimize errors of assignment. Specimens in phase 8 representing individuals ( $\mathrm{N}$ 12; 8 females) were excluded from the analysis because bone quality was highly deteriorated especially in males and measurements were less reliable. Stepwise discriminant function analysis was performed on SPSS to determine the ideal functions to determine sex.

\section{Observation and Result}

Table 1. Descriptive statistics and univariate $F$ ratios.

\begin{tabular}{|c|c|c|c|c|c|c|c|}
\hline \multirow[t]{2}{*}{ Age group } & \multirow[t]{2}{*}{ Variable } & \multicolumn{2}{|r|}{ Male } & \multicolumn{2}{|c|}{ Female } & \multirow[t]{2}{*}{$F$ ratio } & \multirow{2}{*}{ d.f } \\
\hline & & Mean & SD & Mean & SD & & \\
\hline Younger & $\mathrm{N}$ & \multicolumn{2}{|c|}{84} & \multicolumn{2}{|c|}{30} & & \\
\hline & Age & 26.13 & 6.31 & 26.70 & 6.30 & & \\
\hline & $\mathrm{SIH}$ & 15.045 & 1.62 & 12.05 & 1.17 & 85.54 & 1,112 \\
\hline & $\mathrm{APB}$ & 6.81 & .87 & 5.66 & .57 & 44.67 & 2,111 \\
\hline \multirow[t]{4}{*}{ Older } & $\mathrm{N}$ & \multicolumn{2}{|c|}{122} & \multicolumn{2}{|c|}{40} & & \\
\hline & Age & 45.32 & 14.50 & 43.40 & 1.95 & & \\
\hline & $\mathrm{SIH}$ & 15.75 & 1.25 & 12.28 & 1.37 & 221.11 & 1,160 \\
\hline & $\mathrm{APB}$ & 7.62 & 1.01 & 5.43 & .40 & 177.04 & 2,159 \\
\hline \multirow[t]{4}{*}{ Total } & $\mathrm{N}$ & \multicolumn{2}{|c|}{186} & \multicolumn{2}{|c|}{57} & & \\
\hline & Age & 38.20 & 15.64 & 37.15 & 13.94 & & \\
\hline & $\mathrm{SIH}$ & 15.49 & 1.47 & 12.23 & 1.17 & 231.90 & 1,241 \\
\hline & $\mathrm{APB}$ & 7.33 & 1.05 & 5.57 & .50 & 148.58 & 2,240 \\
\hline
\end{tabular}

All dimensions except age are in millimeters. ${ }^{*}$ F ratio shows that differences between the sexes are significant at P, 0.05 levels.

Table 2. Summary of three stepwise Discriminant function analysis.

\begin{tabular}{|c|c|c|c|}
\hline Variables & Wilks' Lambda & Equivalent f ratio & d.f \\
\hline Younger group & \multicolumn{3}{|c|}{} \\
\hline SIH & 0.567 & 85.447 & 1,112 \\
\hline APB & 0.523 & 50.588 & 2,111 \\
\hline Older group & 0.42 & 221.319 & 1,160 \\
\hline SIH & 0.346 & 150.545 & 2,159 \\
\hline APB & \multicolumn{4}{|l}{} \\
\hline Total Group & 0.51 & 231.908 & 1,241 \\
\hline SIH & 0.456 & 143.022 & 2,240 \\
\hline APB & \multicolumn{3}{|l}{}
\end{tabular}

*F ratio shows that differences between the sexes are significant at $\mathrm{P}<0.05$ level.

Table 3. Canonical Discriminant function coefficients.

\begin{tabular}{|c|c|c|c|c|}
\hline $\begin{array}{c}\text { Function and } \\
\text { Varialble }\end{array}$ & $\begin{array}{c}\text { Standardized Canonical Discri- } \\
\text { minant function coefficient }\end{array}$ & $\begin{array}{c}\text { Canonical Discriminant } \\
\text { function coefficient }\end{array}$ & $\begin{array}{c}\text { Structure } \\
\text { matrix }\end{array}$ & $\begin{array}{c}\text { Centroids sectioning } \\
\text { points }\end{array}$ \\
\hline Younger Group & 0.787 & 0.517 & 0.915 & 0.566 \\
\hline SIH & 0.422 & 0.524 & 0.661 & -1.583 \\
\hline APB & & -10.785 & & \\
\hline Constant & \multicolumn{5}{|l|}{} \\
\hline
\end{tabular}




\begin{tabular}{|c|c|c|c|c|}
\hline Older Group & \multicolumn{5}{|l|}{} \\
\hline SIH & 0.68 & 0.531 & 0.854 & 0.783 \\
\hline APB & 0.548 & 0.606 & 0.764 & -2.388 \\
\hline Constant & \multicolumn{5}{|l|}{} \\
\hline Total Group & 0.739 & -12.204 & & \\
\hline SIH & 0.467 & 0.523 & 0.899 & 0.602 \\
\hline APB & \multicolumn{5}{|l|}{0.489} & 0.719 & -1.964 \\
\hline Constant & -11.087 & & \\
\hline
\end{tabular}

These coefficients are used to calculate discriminant scores. Discriminant score formula for young group $=[(\mathrm{SI} \mathrm{mm} \times 0.517)+(\mathrm{AP}$ $\mathrm{mm} \times 0.524)-10.784]$. Discriminant score formula for old group $=[(\mathrm{SI} \mathrm{mm} \times 0.531)+(\mathrm{AP} \mathrm{mm} \times 0.606)-12.204]$.

Positive centroids define male and negative female.

Table 4. Percentage of correction prediction for the discriminant functions.

\begin{tabular}{|c|c|c|c|c|c|c|}
\hline \multirow[t]{2}{*}{ Function and Variables } & \multirow[t]{2}{*}{ Total N } & \multicolumn{2}{|c|}{ Male } & \multicolumn{2}{|c|}{ Female } & \multirow[t]{2}{*}{ Average $\%$} \\
\hline & & $\%$ & $\mathbf{N}$ & $\%$ & $\mathbf{N}$ & \\
\hline \multicolumn{7}{|l|}{ Younger } \\
\hline S-I height & 114 & 83.33 & $70 / 84$ & 86.66 & $26 / 30$ & 84.7 \\
\hline \multicolumn{7}{|l|}{ A-P breadth } \\
\hline \multicolumn{7}{|l|}{ Older group } \\
\hline S-I height & 162 & 86.88 & $106 / 122$ & 82.5 & $34 / 40$ & 86.41 \\
\hline \multicolumn{7}{|l|}{ A-P breadth } \\
\hline \multicolumn{7}{|l|}{ Total group } \\
\hline S-I height & 243 & 82.85 & $153 / 186$ & 82.45 & $47 / 57$ & 82.3 \\
\hline A-P breadth & & & & & & \\
\hline
\end{tabular}

The age distribution, descriptive statistics and a Test of significance between sexes (univariate $\mathrm{f}$ ratio) are shown in Table 1. Stepwise discriminant function Analysis is given in Table 2. Stepwise discriminant Function analysis showed that sex determination was achievable in $83.33 \%$ for males in the young group and $86.66 \%$ for females of the young group and $84.7 \%$ in Total. The most efficient parameter to determine sex was SIH, APB can be used secondly, especially in the Young group. Canonical discriminant function coefficients are shown at Table 3 . The percentage of correct Prediction of age-based functions is shown in Table 4. In the older age group, SIH and APB are both found to be effective sex parameters. The accuracy rate in this group was $86.88 \%$ for males, $82.50 \%$ for Females and $86.41 \%$ in total. As in the young group, the statistical analysis of all cases showed that SIH was the most important parameter to determine Sex. APB could be used next, especially in the Old group. Determination of sex was possible in $82.85 \%$ of males, $82.45 \%$ of females and $82.30 \%$ for all as shown in Table 4. Discriminant formulae were [(SI mm $\times 0.517)+(\mathrm{AP} m \mathrm{~mm} \times 0.524)-10.784]$ for young group and $(\mathrm{SI}$ $\mathrm{mm} \times 0.531)+($ AP $\mathrm{mm} \times 0.606)-12.204]$ for the old group as Shown in Table 3.

\section{Discussion}

Iscan and associates introduced the rib phase techniques nearly 20 years ago [19-21, 27], where they observed that age-related changes were sexually dimorphic [19-21] and this led to the development of separate standards for males and females. Iscan's work [26] indicated that sexual differences in the adult rib can be assessed with great reliability using discriminant function statistics.
It has been demonstrated that ribs show sexual dimorphism not only in the Indian but also in Turkish, North American whites and blacks, as well as in others [26, 28-30]. In 2012 Ravi et.al study revealed that accurate sex determination from the sternal $4^{\text {th }}$ rib could be as high as $94 \%$. It was found that superior inferior height was most potential measurement for sex determination and sexual dimorphism was highest in age group from 40 to 75 years and least in less than 15 year age group [35]. The similar study was done on Turkish population [36] and West African population in Ghana [37] which showed that SI height is most reliable dimension for sexual dimorphism and if both dimensions are taken together it gives an accuracy of $86 \%$ to $90 \%$ in Turkish population and in West African population the accuracy of sex determination varied from $80 \%$ in the young and $74 \%$ in the old groups to $78 \%$ for the total group. Iscan et al [26] study in North American whites and black as well as in others showed the accuracy of sex determination varied from $82 \%$ in the young and $89 \%$ in the old group to $83 \%$ for the combined group.

In kocak et.al study results also indicated that the accuracy of sex determination was $88.6 \%$ in the young group, $86.5 \%$ in the older group. This study indicates that SIH of the rib is the most reliable parameter; APB follows it [38]. The result in our study, accuracy of sex determination was $84.7 \%$ in the young group (phase $1-4$, age $15-32$ ), $86.4 \%$ in the older group (phase $4-8$, age $33-89$ ) is in agreement with kocak et al., in 2003, Iscan et al in 1985 [26], Wiredu EK et al., in 1999, Cologlu AS et al., in 1998 and Ravi et al., in 2012. It should also be noted that these accuracies are on a par with those obtained from other bones like the femur $(80 \%-95 \%)[31,32]$ and tibia $(80 \%-87 \%)[33,34]$. 
Genetic, environmental such as nutrition and climate differences may affect the phenotype of a population. It is known that rib size is both age and population specific. Any formula developed for one population must be carefully assessed before applying it to another population. This fact was the main reason for us to study Iscan's method on the Indian population in Delhi. An accurate sex determination requires knowing the age; at least the subjects are above or below rib phase 4 as in the study by Iscan [26].

\section{Conclusion}

It is concluded, therefore, that the discriminant functions obtained in this study are effective in discriminating between the sexes. This study indicates that sexual dimorphism can be assessed by using a single rib; the right fourth rib in a Indian population from ages 14 to 85 . SIH of the rib is the most reliable parameter followed by APB.

\section{Acknowledgements}

This study would not have been possible without the gracious cooperation of Dr. Yashoda Rani, Professor \& Head and her staff of department Forensic Medicine and Toxicology, Lady Hardinge Medical College, New Delhi-110001, (INDIA). The author is especially grateful to Dr Hariom Kumar Solanki, academic resident at AIIMS for his advice on statistics.

\section{References}

[1]. Krogman WM, Iscan MY (1987) The human skeleton in forensic medicine. Charles C Thomas Publisher, Springfield. 32:452-466.

[2]. Jit I, Singh S (1966) The sexing of adult clavicles. Indian J Med Res 54:551571.

[3]. Coltu A, Dura D, Savci G (1992) Cinsiyet tayininde sternum olculerinin degeri. Adli Tip Derg 8:49-53.

[4]. Jit I, Jhingan V, Kulkarni M (1980) Sexing the human sternum. Am J Phys Anthropol 53:217-224.

[5]. Singh SG, Singh SP, Singh S (1974) Identification of sex from the radius. J Indian Acad Forensic Sci 13:10-16.

[6]. Hanihara K (1958) Sexing diagnosis of Japanese long bones by means of discriminant function. J Anthropol Soc Nippon 66:187-196.

[7]. Lazenby RA (1994) Identification of sex from metacarpals: Effect of side asymmetry. J Forensic Sci 39(5):1188-1194.

[8]. Scheuer JL, Elkington M (1993) Sex determination from metacarpals and the first proximal phalanx. J Forensic Sci 38(4):769-778.

[9]. Falsetti AB (1995) Sex assessment from metacarpals of the human hand. J Forensic Sci 40(5):774-776.

[10]. Smith SL (1996) Attribution of hand bones to sex and population groups. J Forensic Sci 41(3):469-477.

[11]. Smith SL (1997) Attribution of foot bones to sex and population groups. J Forensic Sci 42(2):186-195.

[12]. Marino EA (1995) Sex estimation using the first cervical vertebra. Am J Phys Anthropol 97(2):127-133.
[13]. Iscan MY, Derrick K (1984) Determination of sex from the sacroiliac joint: A visual assessment technique. Am J Phys Anthropol 64:53-57.

[14]. Sundick RI (1977) Age and sex determination of sub adult skeletons. J Forensic Sci 22(1):141-144.

[15]. Huggare J (1992) Population differences in the morphology of the first cervical vertebrae. Am J Phys Anthropol 88(2):197-201.

[16]. Meena MC, Rani Y, Naik SK, Murari A (2012) Age estimation from the IV rib by phase analysis in Indian males. Australian journal of forensic sciences 44(3):261-271.

[17]. Meena MC, Rani Y, Naik SK, Murari A (2012) Age estimation from the IV rib by phase analysis in Indian females. Australian journal of forensic science 45(1): 55-64.

[18]. Meena MC, Rani Y, Rani M (2012) Bilateral metamorphological variation at sternal end of fourth rib. Eurasian journal of anthropology 3(2):41-46.

[19]. Iscan MY, Loth SR, Wright RK (1984) Metamorphosis at the sternal rib end: A new method to estimate age at death in white males. Am J Phys Anthropol 65(2):147-156.

[20]. Iscan MY, Loth SR, Wright RK (1984) Age estimation from the rib by phase analysis: white males. J Forensic Sci 29(4):1094-1104.

[21]. Iscan MY, Loth SR, Wright RK (1985) Age estimation from the rib by phase analysis: white females. J Forensic Sci 30(3):853-863.

[22]. Elkeles A (1966) Sex differences in the calcification of the costal cartilages. J Am Geriatr Soc 14(5):456-462.

[23]. Sanders CF (1966) Sexing by costal cartilage calcification. Br J Radiol 39(459):233.

[24]. Navani S, Shah JR, Levy PS (1970) Determination of sex by costal cartilage calcification. Am J Roentgenol Radium Ther Nucl Med 108(4):771-774.

[25]. McCormick WF, Stewart JH (1983) Ossification patterns of costal cartilages as an indicator of sex. Arch Pathol Lab Med 107(4):206-210.

[26]. Iscan MY (1985) Osteometric analysis of sexual dimorphism in the sternal end of the rib. J Forensic Sci 30(4):1090-1099.

[27]. Iscan MY, Loth SR, Wright RK (1987) Racial variation in the sterna extremity of the rib and its effect on age determination. J Forensic Sci 32(2):452466.

[28]. Loth SR (1966) A comparative analysis of age, sex, and race in the sternal extremity of the rib: A consideration of human skeletal variation. Phys Anthropol 53:217-224.

[29]. Dupras TL, Pfeiffer SK (1996) Determination of sex from adult ribs. Can Soc Forensic Sci J 29:221-231.

[30]. Allen MB (1997) Osteometric variation in ribs: American Blacks. Florida Atlantic University MA Thesis, Boca Raton.

[31]. Iscan MY, Miller-Shaivitz P (1984) Determination of sex from the femur in blacks and whites. Collegium Antropologicum 8:169-75.

[32]. Iscan MY, Ding Shihai (1995) Sexual dimorphism in Chinese femur. Forensic Sci Int 74(1):79-87.

[33]. Iscan MY, Miller-Shaivitz P (1984) Determination of sex from the tibia. Am J Phys Anthropol 64(1):53-57.

[34]. Iscan MY, Yoshino M, Kato S (1994) Sex determination from the tibia: Standards for contemporary Japan. J Forensic Sci 39(3):785-792.

[35]. Gangal R, Yadav M, Chavada VK (2012) Sex Determination from Sternal End of 4th Rib In Western UP Population: An Autopsy Study. J Indian Acad Forensic Med 34(4):332-335.

[36]. Cologlu AS, Iscan MY, Yauvz MF, Sari H (1998) Sex determination from the ribs of contemporary Turks. J Forensic Sciences 43(2):273-276.

[37]. Wiredu EK, Kumoji R, Seshadri R, Biritwum RB (1999) Osteometric Analysis of Sexual Dimorphism in the Sternal End of the Rib in West African Population. J Forensic Sci 44(5):921-925.

[38]. Kocak A, Aktas EO, Erturk S, Aktas S, Yemiscigil A (2003) Sex determination from the sternal end of the rib by osteometric analysis. Legal Medicine 5(2):100-104. 